\title{
The Comparison and Contrast Between the Protectionism and Free Trade in England
}

\author{
Hanya Guan ${ }^{1, a, *, \dagger}$, Pengjun Qian ${ }^{2, b, *, \dagger}$ \\ ${ }^{1}$ Hanya Guan, Beijing National Day School, BNDS, Beijing, China \\ ${ }^{2}$ Pengjun Qian, United World College, UWC, Changshu, China \\ ${ }^{*}$ Corresponding author. Email: ${ }^{a}$ hg357@cornell.edu, ${ }^{b}$ pjqian19@uwcchina.org \\ ${ }^{t}$ These authors contributed equally.
}

\begin{abstract}
International trade is a set of actions that aim to exchange capital, goods, and services between foreign countries across their international borders. International trade policy is a policy related to trading across national boundaries aiming to protect the best interests of their citizens and companies. This article mainly focus on investigating of primary determinants of the international trade policy within a country. This paper summarizes the determinants by reviewing previous articles discussing Britain's international trade policy and analysing the development and advantages of protectionism and free trade policies. This research concludes that globalization has been an indispensable portion existing in international trade system, the free trade policy takes advantage of the global trend; However, considering the historical and political aspects in terms of the international trade, some inevitable past events and political decisions furtherly affect the movement of trade policy. Thus, if the government is reducing the political and historical effects when deciding international trade policies, the tendency of globalization will drive the world into a more connected place.
\end{abstract}

Keywords: protectionism, free trade, England, trade policy, review article

\section{INTRODUCTION}

\subsection{The association of countries---international trade system}

Facilitated by the thriving concept "the global village", the connection and relevance between different countries have developed for several centuries. What associates all the countries is the international trade system, an indispensable component of the global economy. Each country acts with its unique, considered, and profound policies and attempts to occupy the international level in this system. For instance, North America Free Trade Agreement (NAFTA) in the United States has fostered greater integration and helped transform Mexico into a major exporter of manufactured goods [1]. Singapore has recently embarked on what can broadly be termed "new regionalism" and clarified the desire of entering into Free Trade Agreement (FTAs) with other powerhouses like Japan and the United States [2]. In addition, as China becomes more integrated into the international economic institutions and markets, Scott Kennedy points out the porous protectionism in China, discussing the changing political economy of trade policy in China [3].

\subsection{The intersection of the system---England}

By zoom in the details in the trade system, the economists find that a particular country made the transaction between protectionism and free trade-Britain. In the past centuries, economists and politicians argued about the policies decided in Britain. After defeating the French First Empire led by Napoleon in 1815 , Britain became the world's first power, dominating international affairs for a century. This period was called "British rule." Because of this, it became an important country that is the most economically powerful in the world at that time.

To some extent, the British foreign trade policy fundamentally affected the international trade situation at that time. Therefore, by thoroughly studying the foreign trade policy promulgated by the United Kingdom in its most influential period, this paper conduct a macro and microanalysis of the foreign trade policy through the historical background, political influence, and economic 
thinking. The prosperous history of the United Kingdom has adopted different types of foreign trade policies in different periods, the two most significant of which are free trade and protectionism. In general, free trade is the trade based on the unrestricted international exchange of goods with tariffs used only as a source of revenue. In the contrast, protectionism refers to government policies that restrict international trade to help domestic industries, such as tariffs on imported goods, import quotas, and a variety of other government regulations. Moreover, protectionists implemented policies to improve economic activity within a domestic economy and safety or quality concerns. In Britain, the politics and economists combined these two with the political decisions furtherly promote the thriving of Britain's economy during the 16th-20th century.

Understanding the past is always the cornerstone for solving the problem that exists now or in the future. Related to the historical contexts, the past paper written by the previous economic experts had to implement different strategies and policies into various eras to avoid the collapse or the tragedy happened in the United Kingdom. However, most focus on discussing past events and acts, they usually lack the prediction or guide for the future. In terms of this gap, the following essay summarize the determining factors of trade policy and make some predictions for future international trade policy decisions within one country. The analysis includes the past paper's viewpoint, the different policies taken under other circumstances, and how protectionism and free trade influence the country's economy, even the global economy.

\section{LITERATURE REVIEW}

\subsection{The historical background of Britain}

As Professor Mary O'Sullivan discussed British history in his research, in the United Kingdom, the political struggle between supporters of free trade and protectionism began in 1815 [4]. The powerful Gentry in parliament passed the first grain law (corn law) in the 19th century to protect British agriculture from importing foreign grain, political protectionism. However, the power of industrialists increased during the 18th century, and free traders played the idea that rising food prices negatively influenced wages and the laws would reduce the export opportunities as well. After the Whig Party created a favourable free trade situation, in 1845, the happening of the Irish famine and the free trade position supported by the Conservatives and Whigs paved the way for free trade in the U.K. Free trade in Europe started with a French-English treaty and a letter from Napoleon III. This letter is open for informal negotiations with the United Kingdom. The "Cobden-Knight Treaty" abolished the British ban on imports from France, and France reduced its tariffs to an average of $15 \%$ of the value of its products. The negotiations were led by Michel Chevalier, a professor of economics at the French Institute, who pressured then Prime Minister William Gladstone to sign the treaty with his friend Richard Cobden. At the same time, some international elements determine the trend of free trade in Britain because a country's trade policy also comes from the status of each country in the global political, military, diplomatic, economic, and financial fields.

\subsection{Individual firm interests}

Employing the magnifying lens to look at the detail behind protectionism and free trade, Authors Milner and Yoffie demonstrated that ever since Adam Smith and David Ricardo challenged the intellectual foundations of mercantilism, theories of commercial policy have debated the merits of free trade versus protectionism [5]. Since free work was shown to be superior in terms of efficiency, scholars have long puzzled why governments would ever choose protectionism. The authors thought that the main explanation of this phenomenon is the interests of firms because every firm's intention or incentive is to find the optimal outcome [6]. To be more specific, they concluded that the willingness of firms to support free trade or protectionism might be contingent upon the behaviour of their foreign rivals and their governments. For instance, if the firms face comparative disadvantage, they believe they can capture excessive rents through tariffs [7, 8]. In the contrast, there are certain firms prefer free trade. The company with extensive global intra-firm trade flows in the manufacturing sector, is committed to free trade since barriers to trade put a high costs on their business, seeking free trade as a trade strategy. In this case, there is no absolute advantage of either one of the policies. It essentially relies on everything, such as the changes in industry economics, foreign government policy intervention, and variations in industry structure that determine the domestic economic conditions.

Nevertheless, there is no solution when the industries are faced with a combination of competitive pressure and foreign protectionism. In this case, Milner and Yoffie analysed the international trade policy in Britain based on the demands and interests of individual firms. To some extent, the decision of individual firms could significantly influence one country's economy. In this case, the future study should focus on the macro level and realize that the value comes from individuals. The final decision is essentially relevant to the individual's decision.

\subsection{Political power on free trade}

To determine the development of the English Freetrade movement in Parliament in 1689-1702, George L. Cherry (1953) also mentioned that the concepts from 
Adam Smith about the free-trade ideas upon government action had a significant influence on the political and economic decisions [9]. "The nineteenth-century freetrade movement encompassed specific economic principles and concepts, while the seventeenth-century movement was less clearly defined and varied considerably in character during the era." This statement means that sometimes the concept of free trade is slightly different within different contexts, but they are briefly about the attacks on restraints of trade and proposals for free trade. During the era of mercantilism, this paper mainly talked about removing trade constraints in the 19th century in English. The result was a considerable modification of the mercantilist system and the emergence of freer-trade policies. In concluding that, the parliamentary committee, the representatives of the political power, sanctioned the trade balance in the trade, causing the policy to altered.

\subsection{Historical influence on the trade policy}

By drawing on the possibilities of protection combining the political and economic components in England from 1689 to1786, Ralph Davis published a paper about the rise of security in England. The author asserted that for the period when the mercantilist argument was in full flood, a modest flow of works appeared that extolled in one way or another the virtues of free trade [10]. The 1690s were not, as Ashley once suggested, the years when the turn towards free trade began; they were the years when protection began [11]. Specifically, because of the historical background of costly wars, creating a new tariff structure at the end of the seventeenth century rose in response to government demand for money. Thus, rather than implementing a policy derived from economic theories and global economic circumstances, the appearance of protectionism also reflects the historical component in England. What's more, the historical background always related with the cultural factor in the domestic company. In this case, blindly advocating one of the free trade might failed at the end because of lack of considerations of other components.

\subsection{Influential factors on the trade policy}

These studies collectively point out some reasonable explanations for the existence of different strategies and policies under other conditions, like interests of firms, political power impacting the movement, and historical influence on the economic policies. As technology rapidly updates and the information age expands, economic development is growing at an exponential rate. People should be concerned about how they can use the past events to form an international trade policy that could address the obstacles to the growing competitive pressure of the environment and tally with England's political and historical background. pressure of the environment and tally with England's political and historical background.

\section{REVIEW ON THEORY}

\subsection{Development of free trade theory}

In general, free trade based on the unrestricted international exchange of goods with tariffs used only as a source of revenue, which means applying a free-market idea to international trade. Adam Smith first developed the concept of free trade Adam Smith in 1776, who wrote "The Wealth of Nation." In this renowned book, he raised an inconspicuous quote "It is not from the benevolence of the butcher, the brewer, or the baker that we expect our dinner, but from their regard to their own self-interest" [12]. In other words, in the free market, each one's selfinterest can satisfy the others'. Following Smith's logic, the theory of the "invisible hand" was proposed, suggesting a natural force resulting from an individual's decision to make the whole society better off. It was further elaborated by its outcome "price mechanism," saying that buyers and sellers determine the price of a commodity $[12,13]$.

In addition, Smith regarded enlightened and limited government as two of the crucial elements of a country's prosperity [12]. From then on, the proponents of freemarket have believed such a force works well in regulating the economy that there is no need for government to interfere unless it goes beyond control. Last but not least, Smith foresaw the essence of industrialism by determining that division of labor represents a substantial increase in productivity with the typical example of making pins: if pin makers are organized with one making head, one making body, each using different equipment, they can produce 4800 pins a day; in contrast, one person can hardly create one in a whole daytime if he is asked to manipulate all procedures [12]. Since people realized the importance of specialization, more and more diverse and detailed occupations occurred, improving productivity and promoting social well-being through decreasing unemployment.

Following Adam Smith, another accomplished economist called David Ricardo proposed the theory of comparative advantage in 1817 in his remarkable book On the Principles of Political Economy and Taxation, which theatrically proved Adam Smith's foresight [13]. Comparative advantage is an economy's ability to produce a particular good or service at a lower opportunity cost than its trading partners [14]. In other words, suppose there is a specialized good called good A, the country with comparative advantage of good A can maximize their quantity produced if they specialize in creating good A. If each nation possesses its comparative advantage and participates in the international trade, they can not only keep their access to a wide variety of goods 
and services, but also enjoy more quantity of goods than before thanks to the specialization [15]. Over time the theory of comparative advantage has convinced many people of the optimality of free trade. Until now, free trade has become the most popular trading strategy worldwide within the more and more globalized circumstances. Since the free trade policy launched on the international trade system, it had made almost every trading country much more prosperous than before. It enhanced the relationship between them by building connections between the trading partners.

\subsection{Development of protectionism theory}

Protectionism refers to government policies that restrict international trade to help domestic industries, such as tariffs on imported goods, import quotas, and other government regulations. The most common principle is setting taxes. The surcharge raises the price of foreign goods, thus reduce the quantity demanded of such foreign goods and guide the customers to purchase alternative domestic goods, which are relatively cheaper, so the goal of protecting domestic producers is achieved [16].

Most of the proponents of protectionism are partly influenced by Keynesians, led by economist Keynes. Keynesian denies the power of the "invisible hand" introduced by Adam Smith, and conversely, Keynesian believes that the market will finally collapse because of extreme inflation or deflation without government intervention [17]. In this way, although Keynesian does not directly mean protectionism, it still builds the theoretical foundation for protectionism by favoring government intervention. In 1790 Alexander Hamilton proposed a term called "Infant Industry," which refers to a newly-established industry in its early stage of development. Such an industry lacks the experience, customer group, and size to compete effectively with other sectors [18]. In case of bankruptcy, protection from the government needs to ensure the industry can go through the challenging "infant" period until it matures in the market [18].

Moreover, particularly to domestic individuals, the losers in the commercial competition are more identifiable than gainers, meaning they are easier to capture attention and sympathy, creating political pressure emerged from the public, then protectionism follows [19]. Since then, some even took advantage of some existing theories, such as the spill over effect, to argue that protecting one particular industry can stimulate its production, thus creating a profitable supply chain among enterprises, which also favors protectionism. Having such a belief, more and more capitalists who were not satisfied with the industrial supply chain at that time or young industrialists who decided to establish new brands were initiated to advocate tariff setting to pursue profit.

\subsection{The tide of protectionism}

One surge of protectionism in history occurred in Great Depression starting from the 1930s when almost every Western country suffered from economic recession and low employment, so protecting domestic industries alive became the non-negligible priority. After the recession, most countries engaged in free trade, but the ways to protect domestic industries became more and more variable and aggressive. Starting from simple tariffs and quotas, now subsidy on household goods, patent, or even prohibition of selling a particular foreign brand is more and more popular in current global society. Nowadays, America is a country that relies on protectionism the most, which can be proven by its high tariffs set on imported goods and the trade war with China it initiated a few years ago. Learning from the example of Trade War and illustration diagram Figure lbelow, it is not hard to find that although protectionism policies enable the country which implements it to protect the domestic producers by increasing producer surplus by area 1 and increase government revenue by area 3 , it dramatically hurts consumers by cutting down consumer surplus by area $(1+2+3+4)$. As a result, it still creates substantial economic loss, which goes nowhere, to the society, shown by the area $(2+4)$. Even worse, if the country tagged by the policy like China can fight against it by setting tariffs as well, it is a meaningless multi-loss competition.

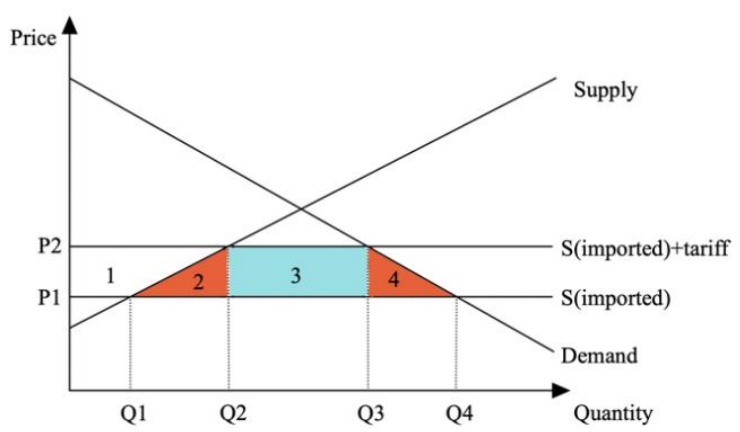

Figure 1 The effect of imposed tariff

\section{RESULTS AND DISCUSSION}

To sum up, the individual company's profits, different historical backgrounds, and political events prompt cause economists to adopt other foreign trade methods in corresponding periods following the development of free trade and protectionism. In recent years, with the globalization of the economy, protectionism is becoming more challenging to adapt to the stage of rapid economic development at this time. Also, free trade, to a certain extent, guarantees the connection between countries. It allows each country involved to use their own comparative advantages to occupy different levels of status in the entire international trading system. Considering the current situation, when COVID-19 pandemic is still present to threaten human society, the 
country which adopts protectionist policies can prevent more population flow attached to international transactions. Based on this, during the COVID-19 pandemic, a part of international trade has to be cut in order to protect the health of people and the stability of national economy.

In previous articles, all foreign trade policies in the UK are inseparable from the unique historical backgrounds. Nowadays, the decision-making upon the trade policy combines the determinant of economic profits and losses and the social scene. At the same time, discussing the correct decision-making of foreign trade is necessary for the policies from all angles from small, each company, to the entire country, and even to the world. The analysis of the predecessors paid more attention to selecting a specific period to analyze the economic decision and social form at that time. However, looking at history vertically, every small policy can pave the way for our subsequent policies because of history and thinking.

However, within the scope of research, there are many authors in the past papers whose positions would be determined according to the author's own bias because economists have their policies regarding the policies adopted in each period. Because of the inherent views, some personal preference is added to the previous paper, making it not objective as expected. At the same time, this paper only has an in-depth study of the UK's international trade policy in the past few centuries. However, this paper lacks the international trade policies adopted by different countries in the world at the same time. If economists can analyze and understand the policies of other countries during the same period, the sufficiency of the data can lead to more general conclusions.

What's more, when there was no large-scale global economization in the past, the multiple-choice questions faced by economists may no longer be the decision of international trade policy but more of the need for local economic development - the adopted intra-national monetary policy. In summary, future studies could focus on the horizontal comparison between different countries within the same period. The focus on the specific country is too narrow to provide a general strategy for all the countries participating in the international trade system. Meanwhile, taking the rapid change around the world into account, it is also indispensable to consider the tread of globalization as one of the important variables for the future investigation.

\section{CONCLUSION}

In conclusion, this review article analyzes the comparison between protectionism and free trade, particularly under the circumstance of England's history between 16th and 20th century. By summarizing the history of England during that period and making literature methodology review, this paper concludes that in theory, free trade occurs when each trading country has its unique comparative advantage that others lack of and each country is willing to exchange within the international trade system, and such a mutually beneficial relationship is established at the cost of being specialized at fewer goods. In contrast, protectionism occurs when a country detects the attack from dominant foreign goods or experiences challenging financial circumstances that cannot be dealt with without extra short-term revenue, implying that counties should not be short-sighted and must adopt cessation of protectionism policy once they recover from the temporary economic recession. Given such a conclusion, the answer to the research question emerges. The future decision on policy direction should be concerned with the production ability of both own countries' interests and trading partners, domestic situation, particularly in the form of historical background and political environment. When it comes to the current pandemic circumstances, which cut off international connection and tightly restrict the flow of money, it is acceptable and understandable that some countries are setting protectionism policies to protect the domestic suppliers. Otherwise, they may suffer from earning no payoff from producing at both labor and land.

Concluding from above, countries must take various respects into serious consideration when setting policy directions since setting which policy direction to execute is closely connected to the future market trend and even the international figure of the country. Whereas countries are not the single stakeholder that should pay attention to such a finding, in detail every individual should be aware of that, because, in most countries such as U.K. and the U.S.A., the implementation of a policy needs to be decided by a democratic vote, attributing much power to the public. If the public has no sense of the pros and cons of free trade and protectionism, the poll may lead to a decision not in favor of the current situation, and oppositely a comprehensive understanding can pave the way for a country's better future with less incidents. Especially, when a country is suffering from the economic shock like COVID-19 pandemic, the irresolution and stagnancy can extremely hurt the domestic economy. In current situation, the tendency of globalization cannot be ignored. Before 1800, the sum of worldwide international trade never exceeded $10 \%$ of global output. After 1820, the first and the second wave of globalization came after the First World War and Second World War respectively. "Today, around $60 \%$ of all goods and services produced in the world are shipped across country borders" [20]. Therefore, considering the globalized trend and the factors listed in the literature review, how to redeem an economy from a potential tragedy is legible.

Although free trade and protectionism is an extensive topic; Having such a belief, more and more capitalists 
who were not satisfied with the industrial supply chain at that time or young industrialists who decided to establish new brands were initiated to advocate tariff setting to pursue profit. An appropriate tailor-made trade policy direction is one of the most indispensable ingredients of one country's future prosperity. Undoubtedly, having a deeper understanding of such two is good for the country and suitable for each living in that country. On top of that, the future studies would focus on the combination and association between free trade and protectionism by reviewing more cases and theories proposed by other countries, rather than those from England according to the generalized trend in the global economy.

\section{REFERENCES}

[1] Blecker, Robert A. "The Mexican and US economies after twenty years of NAFTA." International Journal of Political Economy 43.2 (2014): 5-26.

[2] Rajan, Ramkishen S., Rahul Sen, and Reza Yamora Siregar. Singapore and free trade agreements. ISEAS Publishing, 2001.

[3] Kennedy, Scott. "China's porous protectionism: the changing political economy of trade policy." Political Science Quarterly 120.3 (2005): 407-432.

[4] Mary O'Sullivan. "Between Free Trade and Protectionism: 1846-1914.” Web. Baripedia.org.

[5] Milner, Helen V., and David B. Yoffie. "Between free trade and protectionism: strategic trade policy and a theory of corporate trade demands." International Organization 43.2 (1989): 239-272.

[6] Helen Milner, "Resisting the Protectionist Temptation," Ph.D. diss., Harvard University, 1986; John Odell and I. M. Destler, The Politics of AntiProtection (Washington, D.C.: Institute for International Economics, 1987); and T. Pugel and I. Walter, "U.S. Corporate Interests and the Political Economy of U.S. Trade Policy," Review of Economics and Statistics 67 (August 1985), pp. 46573.

[7] Stolper, Wolfgang F., and Paul A. Samuelson. "Protection and real wages." The Review of Economic Studies 9.1 (1941): 58-73.

[8] Krueger, Anne O. "The political economy of the rent-seeking society." The American economic review 64.3 (1974): 291-303.

[9] Cherry, George L. "The Development of the English Free-Trade Movement in Parliament, 1689-1702." The Journal of Modern History 25.2 (1953): 103119.
[10] Davis, Ralph. "The rise of protection in England, 1689-1786." The Economic History Review 19.2 (1966): 306-317.

[11] Trumbull, Matthew Mark. The free trade struggle in England. No. 81273-81276. Open court publishing Company, 1892.

[12] Smith, Adam, 1723-1790. The Wealth of Nations / Adam Smith ; Introduction by Robert Reich ; Edited, with Notes, Marginal Summary, and Enlarged Index by Edwin Cannan. New York :Modern Library, 2000.

[13] Rothschild, Emma. "Adam Smith and the Invisible Hand." The American Economic Review, vol. 84, no. 2, 1994, pp. 319-322.

[14] Ricardo, David, 1772-1823. The Principles of Political Economy \& Taxation. London : New York :J.M. Dent; E.P. Dutton, 1911.

[15] Maneschi, Andrea. "How Would David Ricardo Have Taught the Principle of Comparative Advantage?" Southern Economic Journal, vol. 74, no. 4, 2008, pp. 1167-1176.

[16] Johnson, Harry G. "An Economic Theory of Protectionism, Tariff Bargaining, and the Formation of Customs Unions.” Journal of Political Economy, vol. 73 , no. 3,1965 , pp. 256-283.

[17] Eichengreen, Barry. "Keynes and Protection." The Journal of Economic History, vol. 44, no. 2, 1984, pp. 363-373.

[18] Melgar, Natalia, et al. "Explaining Protectionism Support: The Role of Economic Factors." ISRN Economics, Hindawi, 17 Jan. 2013, www.hindawi.com/journals/isrn/2013/954071/.

[19] Abboushi, Suhail. "Trade Protectionism: Reasons and Outcomes." Competitiveness Review: An International Business Journal, Emerald Group Publishing Limited, 5 Oct. 2010, www.emerald.com/insight/content/doi/10.1108/105 95421011080760/full/html.

[20] Esteban, Ortiz-Ospina. "Is globalization an engine of economic development?" Our World in Data, 01 Aug. 2017, https://ourworldindata.org/ 